Article

\title{
Statistical Assessment of Water Quality Issues in Hongze Lake, China, Related to the Operation of a Water Diversion Project
}

\author{
Yi Wu ${ }^{1,2}$, Rong Dai ${ }^{2}$, Yongfeng $\mathrm{Xu}^{3,4}$, Jiangang Han ${ }^{1, *}$ and Pingping $\mathrm{Li}^{1, *}$ \\ 1 Co-Innovation Center for the Sustainable Forestry in Southern China, College of Biology and the \\ Environment, Nanjing Forestry University, Nanjing 210037, China; wuyi@nies.org \\ 2 Nanjing Institute of Environmental Sciences, Ministry of Environmental Protection of China, \\ Nanjing 210042, China; dairong@nies.org \\ 3 Key Laboratory of Soil Environment and Pollution Remediation, Institute of Soil Science, Chinese Academy \\ of Sciences, Nanjing 210008, China; yfxu@issas.ac.cn \\ 4 University of Chinese Academy of Sciences, Beijing 100049, China \\ * Correspondence: Hanjiangang76@126.com (J.H.); lipingping@ujs.edu.cn (P.L.)
}

Received: 29 April 2018; Accepted: 30 May 2018; Published: 5 June 2018

check for updates

\begin{abstract}
The Hongze Lake serves as the first important transfer and storage path along the East Route of the South-to-North Water Diversion Project (SNWDP-ER). After the Project began operating in 2013, eutrophication in the lake has created increasing public concern regarding the direct effect on water quality from the project. In this paper, we used multivariate statistical methods to examine the variances between water quality variables at four site groups (inlets and outlets in the study area) and during three seasons (wet, normal, and dry seasons) in Eastern Hongze Lake. We also used redundancy analysis (RDA) to analyze environmental factors' impact on water quality. We found that (1) the concentrations of nitrogen and phosphorus were exceeding the standard values; (2) No significant spatial heterogeneity regarding nitrogen and phosphorus among the inlet/outlet of Eastern Hongze Lake existed in normal and wet seasons, and there was no evidence demonstrating that SNWDP-ER could improve eutrophication or even contribute to eutrophication in the dry season; (3) Environmental factors (land use, water diversion, and population) have limited influences on water quality, which was possibly caused by the overly-high river input and artificial input of nitrogen and phosphorus. Thus, it is critical to reinforce the control of pollution sources and enhance the ecological restoration.
\end{abstract}

Keywords: water quality; multivariate statistical; redundancy analysis; inlet/outlet; Eastern Hongze Lake; South-to-North Water Diversion Project

\section{Introduction}

One of the world's most serious water quality problems is eutrophication, which directly causes toxic algal blooms, fish mortality, declines in biodiversity, and other related ecological problems [1]. In addition, water is much more likely to feature eutrophication due to human activities in densely populated and economically developed areas [2]. However, the major human factors affecting water quality include socio-economic development $[3,4]$, land cover change $[5,6]$, and water conservancy project construction $[7,8]$. Water diversion is included in water conservancy projects, which can change nutrient concentration distributions $[9,10]$.

Earlier studies of water diversion mainly focused on restoring eutrophic lakes. Water diversion and dilution is a common engineering measure in order to directly introduce clean river water to dilute nutrient concentrations, thus controlling lake eutrophication $[11,12]$. Water diversion is often used to 
promote the replacement of lake water with clean river water $[9,13]$. However, previous research has proven that water diversion and the dilution of certain components at different areas will produce varying effects on different aspects of water quality [14,15]. A great deal of previous research also points out that, in fact, the transfer of water may produce negative effects on a system's water quality and biological environment [16], and even aggravate algal outbreaks under some circumstances [17]. Taking this into account, it is necessary to evaluate any impact on eutrophication after the operation of water diversion projects.

The South-to-North Water Diversion Project (SNWDP) was built in order to improve Northern China's water shortages. The Eastern, Western, and Middle routes of the SNWDP transfer water from the Yangtze River to northern regions. Concurrently, there are many eutrophic lakes along the SNWDP's route. A deeper understanding of any impact between these lakes and water diversion would greatly benefit lake management or restoration.

Hongze Lake is the fourth largest freshwater lake in China, and also the first of the regulating lakes along the Eastern Route of the SNWDP (SNWDP-ER) (Figure 1). As the intersection point of the main stream and branches, the Eastern Hongze Lake is both a sink for pollutants from the upper reaches of the Huai River, and a source of pollutants for the Huai River's lower reaches and SNWDP-ER [18]. Several prior studies have found that Hongze Lake has high nutrient pollution; this is mainly owing to nitrogen and phosphorus exceeding standards, causing widespread eutrophication in the lake [19-23]. Therefore, the interrelationship between the Eastern Hongze Lake and the SNWDP-ER could affect the project's water diversion success or failure.

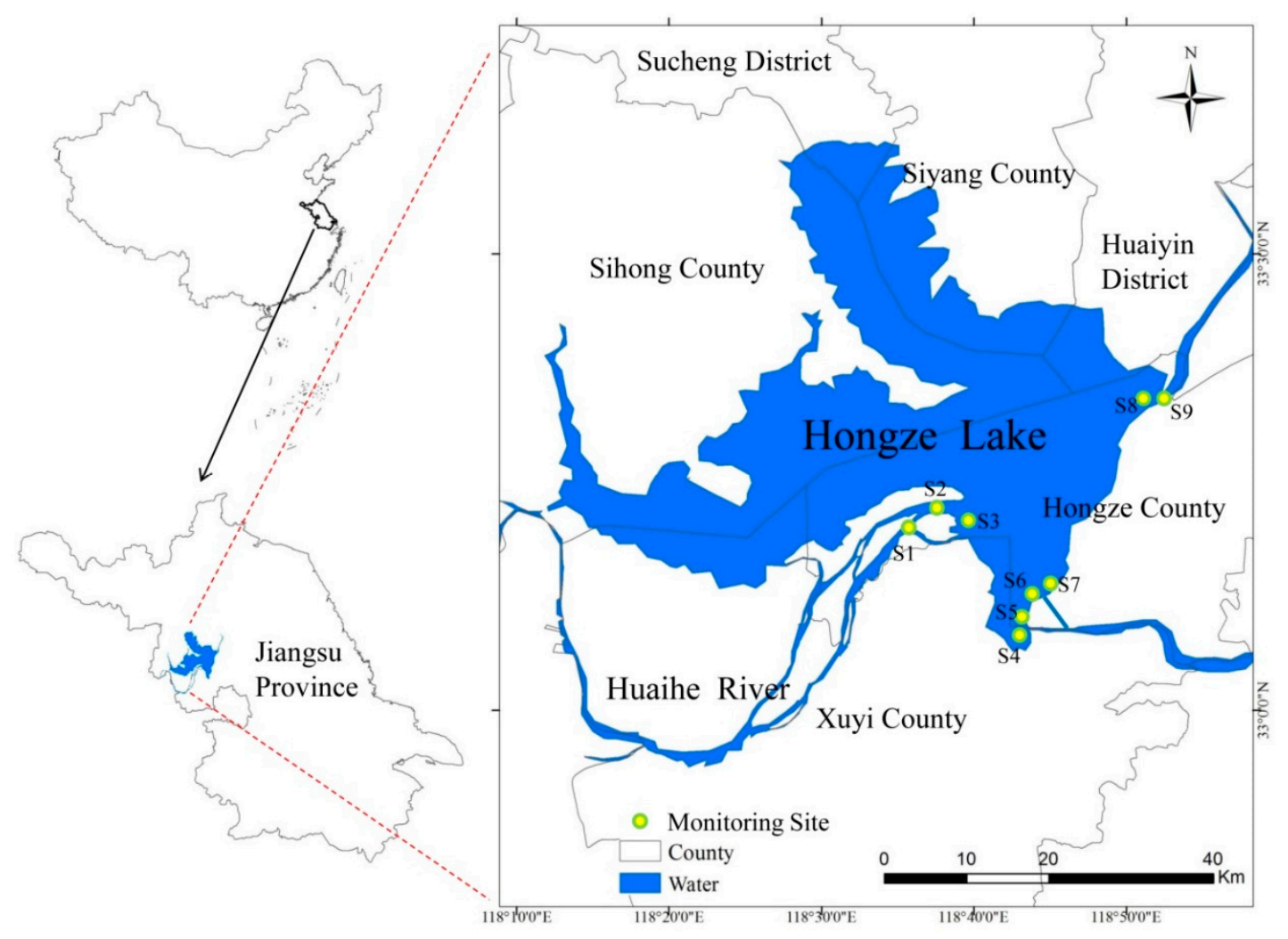

Figure 1. Illustrative map of the Hongze Lake of China.

In addition, after the SNWDP-ER was put into operation in 2013, few studies were performed to analyze water quality at the inlet and outlet of Eastern Hongze Lake. As such, we used multivariate statistical methods to examine the variances between water quality variables at four site groups (inlets and outlets in the study area) and during three seasons (the wet, normal, and dry seasons). We also used redundancy analysis (RDA) to analyze environmental factors' impact on water quality. 
This study's aims were: (1) to characterize the spatiotemporal change of water quality in the Eastern Hongze Lake's important watercourses; (2) to identify the relationship between environmental factors and water quality; and (3) to examine the effects of the SNWDP-ER on water quality. This study may provide information relevant to the restoration of wetlands and serve as a valuable base and reference for the management of the SNWDP-ER, Hongze Lake, and Huai River Basin.

\section{Materials and Methods}

\subsection{Study Area}

Hongze Lake $\left(33^{\circ} 06^{\prime} \mathrm{N}-33^{\circ} 40^{\prime} \mathrm{N}, 118^{\circ} 10^{\prime} \mathrm{E}-118^{\circ} 52^{\prime} \mathrm{E}\right)$ is located in western Jiangsu Province, China. This lake receives water from the main branches of the Huai River, Chi River, New Huaihong River, Xinbian River, and Xinsui River. The lake's catchment is $15.94 \times 104 \mathrm{~km}^{2}$. Hongze Lake has a high water exchange rate and large variations in its water volume; therefore the lake's water level varies seasonally [23]. Hongze Lake serves as the first important transfer-store along the path of the SNWDP-ER. The eastern part of Hongze Lake includes several important inlets and outlets: this is where the Huai River enters the lake and Hongze Lake feeds into the river, as well as the location of the SNWDP-ER's inlet and outlet (Figure 1).

The Huai River is the main source of water for Hongze Lake, accounting for more than $70 \%$ of the lake's total catchment inputs [18]. Hongze Lake's major outlet has two important functions: it serves as the water channel to the San River, which flows into the Yangtze River, while also serving as the water channel to the Yellow Sea and the Main Irrigation Channel for North Jiangsu. In addition, the SNWDP-ER introduced the construction of a new inlet, with the water channel to the Yellow Sea and the Main Irrigation Channel for North Jiangsu as its outlet.

\subsection{Layout of Monitoring Sites and Sample Collection}

Monitoring sites S1-S9 (Figure 1) are located, respectively, at the outlet of the Huai River, the outlet of Hongze Lake flowing into the Yangtze River, the outlet of the SNWDP-ER, and the inlet of the SNWDP-ER, which is also the outlet to the Yellow Sea and irrigation channels (Table 1). These sites were monitored once a month for one year, from August 2014 to July 2015. These months was divided into three seasons based on water level. January to March is the dry season, April to September is the wet season, and October to December is the normal season [23]. Sampling was repeated three times at each monitoring site.

Table 1. The information of monitoring site grouping.

\begin{tabular}{|c|c|c|c|c|c|}
\hline Site Groups & Monitoring Sites & Location & Information & Land Use (LU) & Population (Pop) \\
\hline G2 & S4, S5 & $\begin{array}{l}\text { the outlet of } \\
\text { Hongze Lake }\end{array}$ & $\begin{array}{l}\text { In the location, where the water } \\
\text { from Hongze Lake to Yangtze } \\
\text { River, eventually empty into the } \\
\text { East Sea of China. }\end{array}$ & $\begin{array}{l}\text { Residential } \\
\text { area }\end{array}$ & $\begin{array}{l}\text { Third largest } \\
\text { population } \\
\text { (small town) }\end{array}$ \\
\hline G3 & S6, S7 & $\begin{array}{l}\text { the outlet of } \\
\text { SNWDP-ER }\end{array}$ & $\begin{array}{c}\text { In the location, a new inlet has } \\
\text { been built by the SNWDP-ER } \\
\text { between the Yangze River and } \\
\text { Honze Lake. }\end{array}$ & Farmland & $\begin{array}{l}\text { The minimum } \\
\text { population } \\
\text { (village) }\end{array}$ \\
\hline G4 & S8, S9 & $\begin{array}{l}\text { the inlet of } \\
\text { SNWDP-ER }\end{array}$ & $\begin{array}{l}\text { In the location, the inlet of } \\
\text { SNWDP-ER (S4). This is also the } \\
\text { outlet to the Yellow Sea and the } \\
\text { Subei Irrigation Channel. }\end{array}$ & Urban area & $\begin{array}{l}\text { Largest population } \\
\text { (urban) }\end{array}$ \\
\hline
\end{tabular}

The monitoring sites where water samples were collected were required to be at least $5 \mathrm{~m}$ from the river bank, and 0.5-m-deep when measured from the surface of the water. Samples were collected 
by using $1000 \mathrm{~mL}$ organic glass hydrophores. Sampling was repeated three times at each monitoring site. The samples were stored in iceboxes until analyzed.

We choose eight water parameters. All of these parameters are related to water pollution indicators, which are also influenced by anthropogenic activities. The three data parameters, electrical conductivity (EC), dissolved oxygen (DO), and $\mathrm{pH}$, were obtained through on-site measurement using a HQ30d water quality analyzer at monitoring sites. Other parameters were obtained through laboratory experimentation. Total nitrogen (TN) was measured with ultraviolet spectrophotometry (UV2800, UNICO Company, San Diego, CA, USA). Total phosphorus (TP), ammonium nitrogen $\left(\mathrm{NH}_{3}-\mathrm{N}\right)$, and chlorophyll-a (Chl-a) were measured with a spectrophotometer (DR2800, Hach Company, Loveland, CO, USA). Chemical oxygen demand (COD $\mathrm{Mn})$ was measured using the potassium permanganate method.

\subsection{Data Analysis}

Multivariate statistical analyses were widely applied to the water quality distribution analysis [25-28]. Non-parametric tests were employed to evaluate data normality [29]. The Levene test was applied to analyze the homogeneity of variance in the data. Multiple comparisons using the Dunnett's test were used to identify if there is a significant difference in water quality among monitoring site groups. Redundancy analysis (RDA) and spearman rank correlation analysis were used to identify the relationship between water quality parameters and environmental variables [30]. The SPSS 17.0 and CANOCO 5.0 were used to deal with multivariate statistical analysis and redundancy analysis, respectively.

\section{Results}

\subsection{Water Quality in Eastern Hongze Lake}

Data from the monitoring sites at important water channels in the eastern part of Hongze Lake showed that the TP values ranged from 0.02 to $0.22 \mathrm{mg} / \mathrm{L}$ (mean value was $0.11 \mathrm{mg} / \mathrm{L}$ ), TN values ranged from 1.63 to $1.97 \mathrm{mg} / \mathrm{L}$ (mean value was $1.78 \mathrm{mg} / \mathrm{L}$ ), $\mathrm{NH}_{3}-\mathrm{N}$ values ranged from 0.4 to $0.61 \mathrm{mg} / \mathrm{L}$ (mean value was $0.48 \mathrm{mg} / \mathrm{L}$ ), $\mathrm{COD}_{\mathrm{Mn}}$ values ranged from 3.9 to $6 \mathrm{mg} / \mathrm{L}$ (mean value was $4.67 \mathrm{mg} / \mathrm{L}$ ), Chl-a values ranged from 11.19 to $16.67 \mu \mathrm{g} / \mathrm{L}$ (mean value was $13.12 \mu \mathrm{g} / \mathrm{L}$ ), DO values ranged from 5.64 to $11.8 \mathrm{mg} / \mathrm{L}$ (mean value was $8.5 \mathrm{mg} / \mathrm{L}$ ), EC values ranged from 21.7 to $53.9 \mu \mathrm{s} / \mathrm{cm}$ (mean value of $36.02 \mu \mathrm{s} / \mathrm{cm}$ ), and $\mathrm{pH}$ values ranged from 6.76 to 9.32 (mean value was 8.38) (Figure 2).

The concentrations of water quality parameters during wet, normal, and dry seasons in monitoring sites are displayed in Table 2. The mean concentration of TN was lowest in the dry season and highest in the wet season. On the contrary, the mean concentration of DO was highest in the dry season and lowest in the wet season. The mean concentrations of TP and $\mathrm{COD}_{\mathrm{Mn}}$ were highest in the normal season and lowest in the dry season. Meanwhile, the mean concentration of $\mathrm{NH}_{3}-\mathrm{N}$ did not vary much during the three seasons.

Table 2. Summary of surface water quality in three seasons.

\begin{tabular}{|c|c|c|c|c|}
\hline \multirow{2}{*}{$\begin{array}{c}\text { Water Quality } \\
\text { Parameters (Units) }\end{array}$} & Dry Season & Normal Season & Wet Season & \multirow{2}{*}{$\begin{array}{c}\text { Standard for } \\
\text { Grade III }\end{array}$} \\
\hline & Mean \pm S.D. & Mean \pm S.D. & Mean \pm S.D. & \\
\hline $\mathrm{EC}(\mu \mathrm{s} / \mathrm{cm})$ & $45.99 \pm 6.09$ & $39.21 \pm 5.78$ & $29.44 \pm 3.04$ & \\
\hline $\mathrm{pH}$ & $8.66 \pm 0.23$ & $8.24 \pm 0.38$ & $8.30 \pm 0.45$ & \\
\hline $\mathrm{DO}(\mathrm{mg} / \mathrm{L})$ & $9.57 \pm 1.03$ & $9.83 \pm 0.77$ & $7.29 \pm 0.6$ & $\geq 5.0$ \\
\hline $\mathrm{COD}_{\mathrm{Mn}}(\mathrm{mg} / \mathrm{L})$ & $4.44 \pm 0.3$ & $4.87 \pm 0.55$ & $4.69 \pm 0.36$ & $\leq 6.0$ \\
\hline Chl-a $(\mu \mathrm{g} / \mathrm{L})$ & $11.88 \pm 0.5$ & $13.31 \pm 1.3$ & $13.64 \pm 1.14$ & \\
\hline $\mathrm{TN}(\mathrm{mg} / \mathrm{L})$ & $1.73 \pm 0.05$ & $1.79 \pm 0.08$ & $1.81 \pm 0.05$ & $\leq 1.0$ \\
\hline $\mathrm{TP}(\mathrm{mg} / \mathrm{L})$ & $0.07 \pm 0.02$ & $0.15 \pm 0.04$ & $0.10 \pm 0.04$ & $\leq 0.05$ \\
\hline $\mathrm{NH}_{3}-\mathrm{N}(\mathrm{mg} / \mathrm{L})$ & $0.48 \pm 0.04$ & $0.47 \pm 0.05$ & $0.48 \pm 0.04$ & $\leq 1.0$ \\
\hline
\end{tabular}



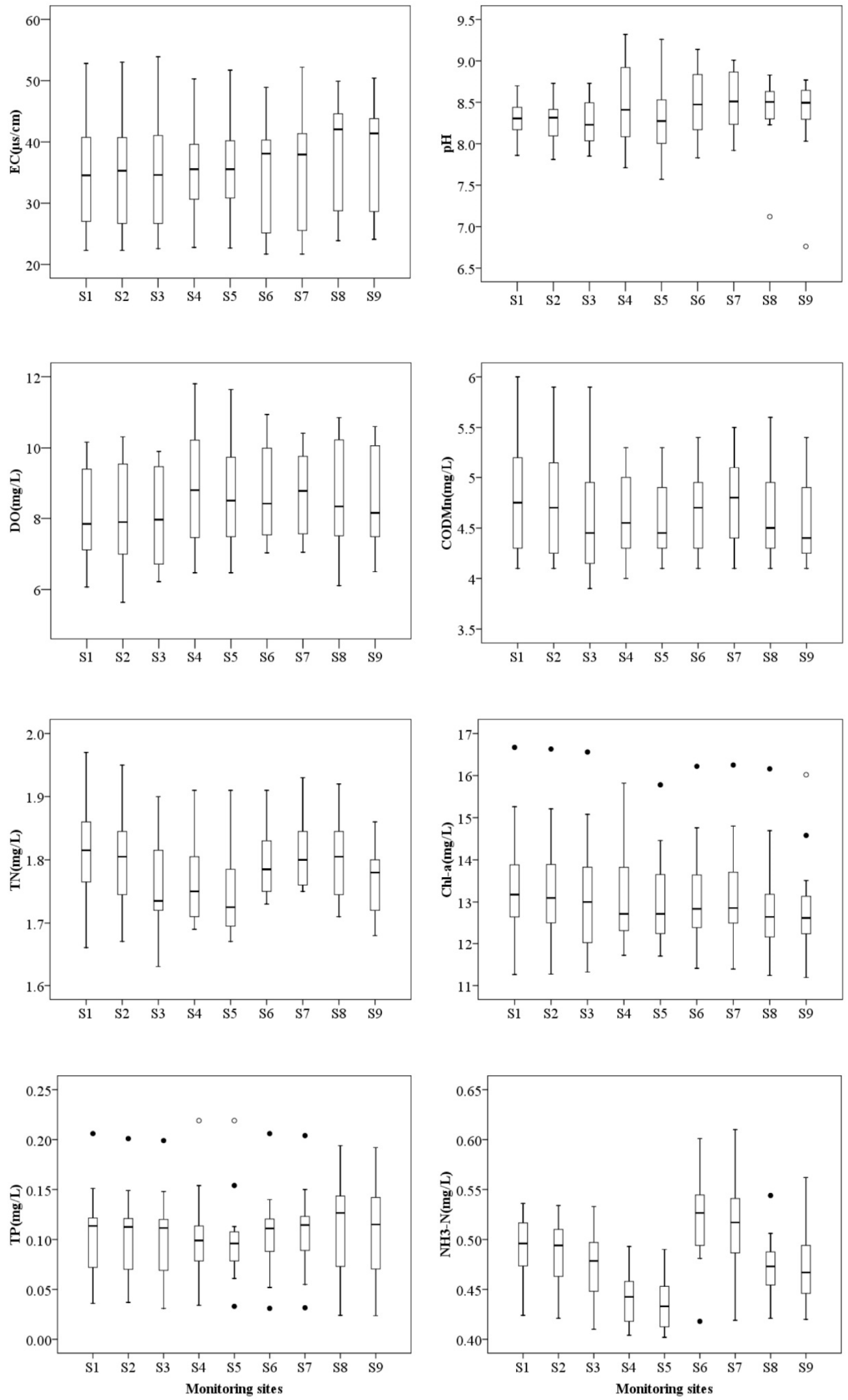

Figure 2. Water quality of monitoring sites in the eastern part of Hongze Lake. Solid circle is extreme value; hollow circle is discrete value. 
According to China's Environmental Quality Standards for Surface Water (GB3838-2002), the mean concentrations of TP and TN were far in excess of Grade III values. The mean concentrations of $\mathrm{NH}_{3}-\mathrm{N}$ and $\mathrm{COD}_{\mathrm{Mn}}$ were below the standard value. The mean concentration of $\mathrm{DO}$ was much higher than the standard value. These values indicate that there was a serious risk of eutrophication in Eastern Hongze Lake.

\subsection{Temporal and Spatial Variations of Water Quality among Site Groups}

As shown in Figure 3, the results of multiple comparative analyses prove that the five water quality parameters of G1, G2, G3, and G4 groups exhibit some changes. In normal and wet seasons, the average concentration of ammonium nitrogen in the G3 group is significantly higher than that of the other groups $(p<0.05)$. In the dry season, the average concentration of TN in the G2 group is significantly lower than that of the other groups $(p<0.05)$, the average concentration of total phosphorus in the G1 group is significantly lower than that of the other groups $(p<0.05)$. In dry and normal seasons, the average concentration of EC in the G4 group is significantly higher than that of G2 and G3 groups $(p<0.05)$. In normal and wet seasons, the average concentration of DO in the G1 group is significantly lower than that of G3 and G4 groups $(p<0.05)$. Meanwhile, there were no significant variations detected in $\mathrm{pH}, \mathrm{COD}_{\mathrm{Mn}}$, and Chl-a. The mean concentration of $\mathrm{TN}$ in all groups was over $1.0 \mathrm{mg} / \mathrm{L}$ during all three seasons, as the TP was over $0.05 \mathrm{mg} / \mathrm{L}$. When comparing this data with the values outlined in the Grade III water standard shows, our research indicates that water pollution is serious in the study area.
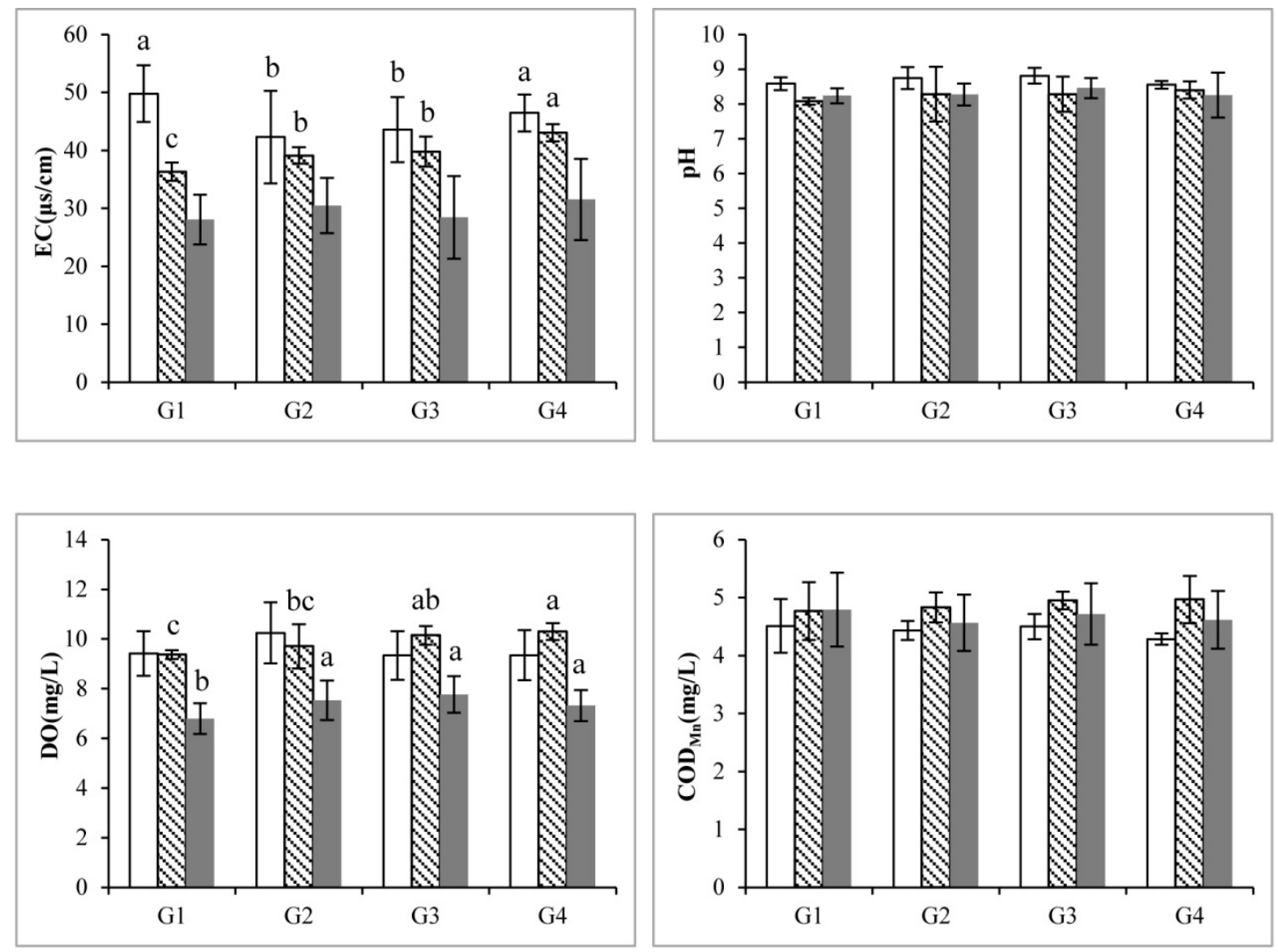

Figure 3. Cont. 

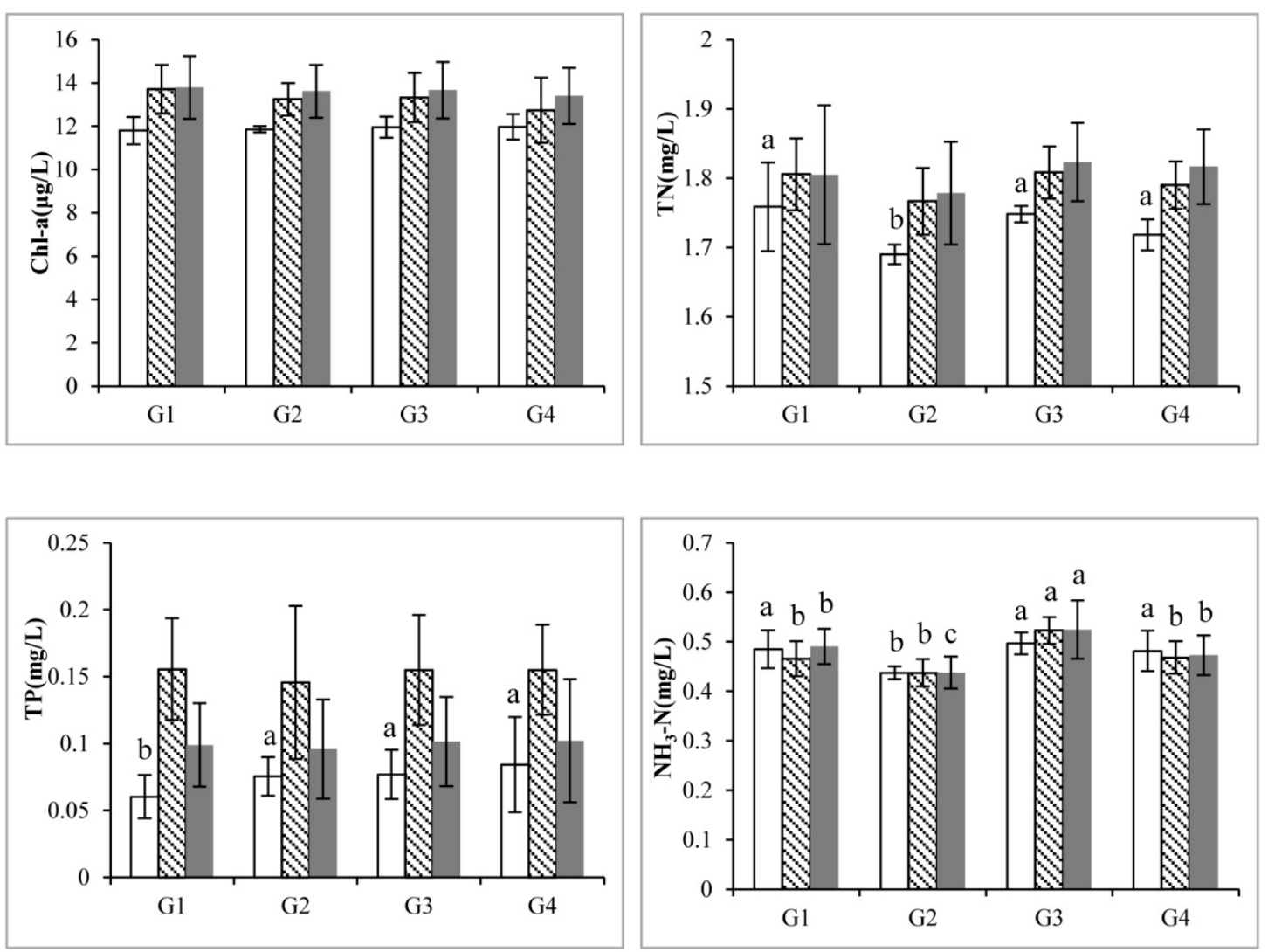

Dry season $\quad$ W Normal season $\quad$ Weason

Figure 3. Mean \pm standard error values for the water quality parameters among G1, G2, G3, and G4 in the dry, normal, and wet seasons.

\subsection{The Correlation between Environmental Factors and Water Quality}

As observable from the results of the RDA, in the normal season, the canonical axis eigenvalue creates the highest contribution to changes in water quality, with a contribution of only $28.61 \%$ (pseudo-F $=3.1, p<0.01$ ). Despite this, in other seasons, the contribution is much lower. As shown in Table 3, the first axle displays data pertaining to water quality changes in the normal season, accounting for $25.93 \%$ (pseudo-F $=8.1, p<0.01$ ), and presenting a positive correlation with LU (land use), as shown in Figure 4. The second axle accounts for less than $3 \%$ of changes (insignificant), and this is mainly determined by WD (water diversion). These values demonstrated that water quality had an insignificant correlation with land use, water diversion, and population. While land use negatively correlated with $\mathrm{TN}, \mathrm{TP}$, and $\mathrm{NH}_{3}-\mathrm{N}$ in normal and dry seasons, and water diversion positively correlated with these nutrient parameters in all seasons. According to Table 4, as seen from a correlation analysis, $\mathrm{TN}, \mathrm{TP}$, and $\mathrm{NH}_{3}-\mathrm{N}$ present a negative correlation with $\mathrm{LU}$, and present a positive correlation with WD. In particular, $\mathrm{NH}_{3}-\mathrm{N}$ presents a significantly positive correlation with $\mathrm{WD}(\mathrm{r}>0.48, p<0.01)$. Chl-a presents a negative correlation with LU and WD $(\mathrm{r}<-0.34, p<0.05)$, and presents a positive correlation with EC and DO $(r>0.5, p<0.01)$. 
Table 3. The results of RDA: the explained variance (\%) of the water quality parameters.

\begin{tabular}{|c|c|c|c|c|c|c|c|c|c|}
\hline \multirow[b]{2}{*}{$\begin{array}{l}\text { Axes and } \\
\text { Variables }\end{array}$} & \multicolumn{3}{|c|}{ Dry Season } & \multicolumn{3}{|c|}{ Normal Season } & \multicolumn{3}{|c|}{ Wet Season } \\
\hline & $\begin{array}{c}\text { Explained } \\
\text { Variation } \\
(\%)\end{array}$ & Pseudo-F & $p$ Value & $\begin{array}{l}\text { Explained } \\
\text { Variation } \\
(\%)\end{array}$ & Pseudo-F & $p$ Value & $\begin{array}{c}\text { Explained } \\
\text { Variation } \\
(\%)\end{array}$ & Pseudo-F & $p$ Value \\
\hline \multicolumn{10}{|c|}{ Canonical axes } \\
\hline First axis & 16.25 & 4.5 & 0.114 & 25.93 & 8.1 & $0.002 * *$ & 4.98 & 2.6 & 0.278 \\
\hline $\begin{array}{l}\text { Second } \\
\text { axis }\end{array}$ & 2.4 & 0.7 & 0.774 & 2.55 & 0.8 & 0.802 & 2.9 & 1.6 & 0.442 \\
\hline all axes & 19.73 & 1.9 & 0.102 & 28.61 & 3.1 & $0.002 * *$ & 8.19 & 1.5 & 0.518 \\
\hline \multicolumn{10}{|c|}{ Explanatory variables } \\
\hline LU & 8.8 & 2.5 & 0.092 & 21.4 & 6.8 & $0.002 * *$ & 4.6 & 2.5 & 0.072 \\
\hline WD & 4.4 & 1.3 & 0.292 & 6.9 & 2.9 & $0.047^{*}$ & 1 & 0.5 & 0.628 \\
\hline Pop & 6.6 & 1.8 & 0.16 & 0.3 & 0.1 & 0.99 & 2.6 & 1.4 & 0.204 \\
\hline
\end{tabular}

The values of pseudo-F and $p$ were chiefly obtained through the Monte Carlo permutation test. LU, WD, and Pop indicate the land use, water diversion, and population, respectively. ${ }^{*} p<0.05 ;{ }^{* *} p<0.01$.

Table 4. The spearman correlation analysis between water quality parameters and environmental variables in the three seasons.

\begin{tabular}{cccccccccc}
\hline & \multicolumn{3}{c}{ Wet Season } & \multicolumn{3}{c}{ Normal Season } & \multicolumn{3}{c}{ Dry Season } \\
\cline { 2 - 10 } & LU & WD & Pop & LU & WD & Pop & LU & WD & Pop \\
\hline $\mathrm{EC}$ & 0.25 & 0.00 & 0.13 & $0.75^{* *}$ & $0.63^{* *}$ & 0.20 & -0.33 & -0.26 & 0.38 \\
$\mathrm{pH}$ & 0.18 & $0.27^{*}$ & -0.01 & 0.22 & 0.29 & 0.26 & -0.06 & -0.04 & $-0.46^{*}$ \\
$\mathrm{DO}$ & $0.32 *$ & $0.31^{*}$ & -0.25 & $0.57^{* *}$ & $0.61^{* *}$ & -0.05 & 0.07 & -0.17 & -0.05 \\
$\mathrm{COD}$ & -0.12 & 0.00 & -0.02 & 0.02 & 0.12 & 0.02 & -0.22 & -0.12 & -0.31 \\
$\mathrm{Chl}-\mathrm{a}$ & -0.21 & -0.14 & -0.09 & $-0.42^{*}$ & $-0.34^{*}$ & -0.10 & 0.11 & 0.15 & -0.08 \\
$\mathrm{TN}$ & 0.01 & 0.22 & 0.02 & -0.24 & 0.08 & -0.07 & $-0.50^{* *}$ & 0.12 & -0.07 \\
$\mathrm{TP}$ & 0.00 & 0.14 & 0.08 & -0.01 & 0.12 & 0.11 & 0.31 & 0.28 & -0.11 \\
$\mathrm{NH}_{3}-\mathrm{N}$ & $-0.29^{*}$ & 0.27 & -0.15 & -0.14 & $0.48^{* *}$ & -0.26 & -0.31 & 0.32 & -0.02 \\
\hline
\end{tabular}
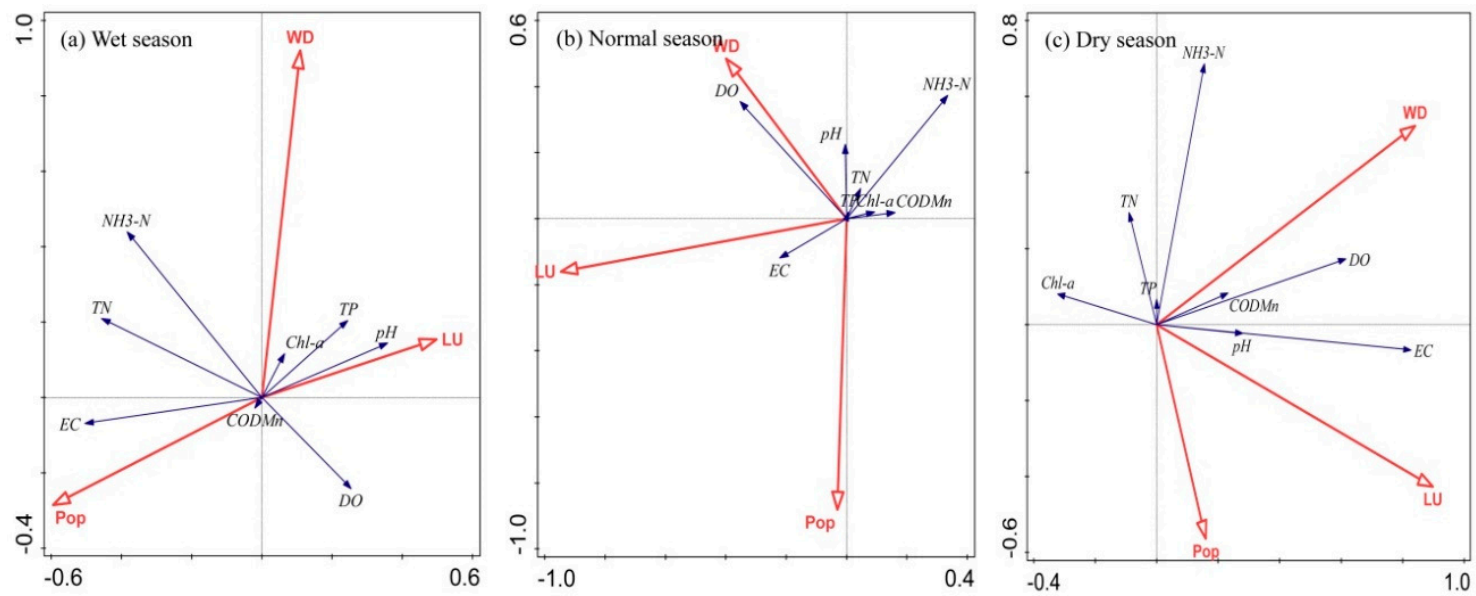

Figure 4. The results of RDA: water quality parameters and environmental variables in the wet season (a); normal season (b); and dry season (c).

\section{Discussion}

There are several important characteristics in the temporal and spatial variation of water quality in important inlets/outlets along the Eastern Hongze Lake. The mean concentration of TN and $\mathrm{TP}$ is $1.78 \mathrm{mg} / \mathrm{L}$ and $0.11 \mathrm{mg} / \mathrm{L}$, respectively, both of which are far higher than Grade-III standard values. Previous research has proven that from 2006 to 2011, the annual mean concentration of 
TN in Hongze Lake rose from $0.792 \mathrm{mg} / \mathrm{L}$ to $2.259 \mathrm{mg} / \mathrm{L}$, and that of TP rose from $0.098 \mathrm{mg} / \mathrm{L}$ to $0.142 \mathrm{mg} / \mathrm{L}$ [21]. The comparison of our research results with previous research results from 2011 shows that the concentration of TN and TP in the Eastern Hongze Lake has undergone no obvious changes. Thus, eutrophication is still a major threat to Hongze Lake following the establishment of the SNWDP-ER in 2013. Meanwhile, nitrogen and phosphorus are still major pollutants.

We found that there was no significant spatial heterogeneity for TN and TP among G1, G2, G3, and G4 in the normal and wet seasons. This may have been highly influenced by the operation of the SNWDP-ER, which requires closing water gates to Hongze Lake in order to maintain high water levels during most months. Then, the lake tends to retain nutrients [31]. Human activities were the main threat to water quality [32]. Excessive purse-seine fishing and dike farming activities around the lake are major causes of many lakes' ecological degradation in China's eastern plain [33]. Agricultural activities in neighboring coastal areas continuously add nitrogen and phosphorus into the lake [34]. There is also a large amount of enclosed cultivation and aquatic breeding in the Eastern Hongze Lake, and the discharge of pond wastewater further increases nitrogen and phosphorus concentrations [35]. However, population growth has a significant impact on water quality [36]. Additionally, the study area is an important population gathering area around the Hongze Lake.

The variance analysis demonstrates that G1 had the lowest phosphorus concentration and G2 had the lowest nitrogen concentration in the dry season. For SNWDP-ER, it has to maintain a relatively high water level by controlling the water output. Then, the water velocity in outlets of the Huai River and Hongze Lake were relatively high in the dry season, which accelerates the movements of nitrogen and phosphorus [37,38]. Moreover, the silt transported by rivers can also absorb major nutrient salts [39]. At the same time, the rich biological groups in the intersection area of the river and lake can play an effective role in the removal of nutrient salts. This can subsequently reduce concentrations of nitrogen and phosphorus [40-42]. Abundant aquatic life at this intersection between the river and the lake can also remove nutrients $[43,44]$.

Previous studies have suggested that Hongze Lake should function in the drawdown of nutrients, so that nitrogen concentration at the end of the flow path, which includes the lake itself, should be lower [45]. However, there is no significant difference in the nitrogen and phosphorus concentrations between sites G3 and G4. Our study showed that Hongze Lake plays a limited role in the removal of nitrogen and phosphorus during water diversion along the SNWDP-ER. In contrast, the SNWDP-ER may contribute to eutrophication in the dry season. The resulting changes in hydrology may have led to higher a total nitrogen concentration in the Yangtze River than that of Hongze Lake [46]. Meanwhile, the distance between the inlet and outlet of SNWDP-ER is less than $30 \mathrm{~km}$. Water's flow speed was accelerated and water exchange volume was increased by the SNWDP-ER [24]. These limit the purification capability of the lake. In addition, there is a concrete dam for resisting floods, which has almost no absorption of nutrient salts.

Previous studies have also suggested that land use [47], water diversion [9], and population [36] have a strong relationship with water quality. Our research results highlight that these environmental factors have insignificant influences on the water quality in Eastern Hongze Lake. However, the nutrition parameters still have a negative correlation with land use, and present a positive correlation with the existence of water diversion. The results are possibly caused by the overly-high river input [48] and artificial input [49] in the study area. In addition, agricultural water use and large amounts of rainfall both play important roles in dilution [50]. Thus, nitrogen and phosphorus transported by river and water diversion represent the key problem in managing eutrophication in the study area. In order to reduce the input of pollution and improve the lake's purification capability in the short term, the control strategies should focus on: (1) developing ecological agriculture with a reasonable application of fertilizer and pesticides; (2) carrying out comprehensive improvement of aquaculture, and integrating and optimizing the aquaculture model; (3) improving the treatment of sewage and recycling of agricultural wastes; (4) increasing aquatic vegetation and optimizing the configuration of plants; and (5) building a water quality purification project of artificial wetland in 
the outlet of SNWDP-ER. However, river basin management and decreasing human activities are the more effective measures to control eutrophication in the long-term [51]. So, strengthening government guidance and improving people's protection can be considered as the main management policies and measures to control eutrophication in the future.

\section{Conclusions}

In summary, the ecology of Hongze Lake is threatened because of high nutrient concentrations in the water, especially TN and TP, which exceed the lake's self-purification capability and lead to eutrophication. The results showed that there are no helpful improvement solutions for the eutrophication problem created by the SNWDP-ER, and the lake was also not useful in purifying water quality in water diversion. This not only affects lake-based industries, but also drinking water and the health of local residents. To maintain the geographic and ecological services provided by Hongze Lake, it is critical to reinforce the control of pollution sources and exploit the ecological restoration potential of wetlands to improve the lake's self-purification capability.

Author Contributions: Y.W., J.H., and P.L. designed the study; Y.W. and R.D. developed the methods; Y.W. and Y.X. collected the data; Y.W. conducted the analyses; Y.W. and R.D. wrote the paper.

Acknowledgments: We are grateful to Huai Yang, Qingyong Sun, and Zhuofei Sun from the Laozishan Forestry Farm of Hongze County, China. This work was supported by the National Natural Science Foundation of China (Grant No. 41375149); the Natural Science Foundation of Jiangsu Province, China (Grant No. BK20160103); a Project Funded by the Priority Academic Program Development of Jiangsu Higher Education Institutions (PAPD); the Forestry SanXin Project of Jiangsu Province of China (Grant No. lysx [2013] 09); and the Central Public-interest Scientific Institution Basal Research Fund (Grant No. GYZX180203).

Conflicts of Interest: The authors declare no conflict of interest. The founding sponsors had no role in the design of the study; in the collection, analyses, or interpretation of data; in the writing of the manuscript, and in the decision to publish the results.

\section{References}

1. Paer, H. Assessing and managing nutrient enhanced eutrophication in estuarine and coastal waters: Interactive effects of human and climatic perturbations. Ecol. Eng. 2006, 26, 40-54. [CrossRef]

2. Schindler, D. The dilemma of controlling cultural eutrophication of lakes. Proc. R. Soc. B 2012, 279, 4322-4333. [CrossRef] [PubMed]

3. Min, P.; Lu, G. The influence of socio-economic development on water quality in the Dianchi Lake. Eng. Sci. 2010, 12, 117-122.

4. Malsy, M.; Flörke, M.; Borchardt, D. What drives the water quality changes in the Selenga Basin: Climate change or socio-economic development? Reg. Environ. Chang. 2017, 17, 1977-1989. [CrossRef]

5. Bhandari, S.; Sridhar, B.B.M.; Wilson, B.L. Effect of Land Cover Changes on the Sediment and Water Quality Characteristics of Brays Bayou Watershed. Water Air Soil Pollut. 2017, 228, 336. [CrossRef]

6. Uwimana, A.; Van, D.A.; Gettel, G.; Bigirimana, B.; Irvine, K. Effects of river discharge and land use and land cover (LULC) on water quality dynamics in migina catchment, rwanda. Environ. Manag. 2017, 60, 496-512. [CrossRef] [PubMed]

7. Zhang, Y.; Xia, J.; Liang, T.; Shao, Q. Impact of water projects on river flow regimes and water quality in huai river basin. Water Resour. Manag. 2010, 24, 889-908. [CrossRef]

8. Liu, J.; Zang, C.; Tian, S.; Liu, J.; Yang, H.; Jia, S.; You, L.; Liu, B.; Zhang, M. Water conservancy projects in china: Achievements, challenges and way forward. Glob. Environ. Chang. 2013, 23, 633-643. [CrossRef]

9. Zhang, X.; Zou, R.; Wang, Y.; Liu, Y.; Zhao, L.; Zhu, X.; Guo, H. Is water age a reliable indicator for evaluating water quality effectiveness of water diversion projects in eutrophic lakes. J. Hydrol. 2016, 542, 281-291. [CrossRef]

10. Stolf, R.; Piedade, S.M.D.; Da Silva, J.R.; Da Silva, L.C.F.; Maniero, M.A. Water transfer from Sao Francisco River to semiarid northeast of Brazil: Technical data, environmental impacts, survey of option about the amount to be transferred. Eng. Agríc. 2012, 32, 998-1010. [CrossRef] 
11. Amano, Y.; Sakai, Y.; Sekiya, T.; Takeya, K.; Taki, K.; Machida, M. Effect of phosphorus fluctuation caused by river water dilution in eutrophic lake on competition between blue-green alga Microcystis aeruginosa and diatom Cyclotella sp. J. Environ. Sci. 2010, 22, 1666-1673. [CrossRef]

12. Zou, R.; Zhang, X.; Liu, Y.; Chen, X.; Zhao, L.; Zhu, X.; He, B.; Guo, H. Uncertainty-based analysis on water quality response to water diversions for Lake Chenghai: A multiple-pattern inverse modeling approach. J. Hydrol. 2014, 514, 1-14. [CrossRef]

13. Liu, Y.; Wang, Y.; Sheng, H.; Dong, F.; Zou, R.; Zhao, L.; Guo, H.; Zhu, X.; He, B. Quantitative evaluation of lake eutrophication responses under alternative water diversion scenarios: A water quality modeling based statistical analysis approach. Sci. Total Environ. 2014, 468, 219-227. [CrossRef] [PubMed]

14. Hu, W.; Zhai, S.; Zhu, Z. Impacts of the Yangtze River water transfer on the restoration of Lake Taihu. Ecol. Eng. 2008, 34, 30-49. [CrossRef]

15. Li, Y.; Acharya, K.; Yu, Z. Modeling impacts of Yangtze River water transfer on water ages in Lake Taihu, China. Ecol. Eng. 2011, 37, 325-334. [CrossRef]

16. Lepono, T.; Du, P.H.; Thokoa, M. Monitoring of water transfer from Katse dam into the upper Vaal river system: Water utility's perspective. Water Sci. Technol. 2003, 48, 97-102. [CrossRef] [PubMed]

17. Xie, P.; Xu, B.; Xiao, C. Effects of the middle route of china's south-to-north water transfer project on water environment in the middle-downstream of Hanjiang River. IAHS-AISH Publ. 2011, 350, 283-289.

18. Li, S.; Guo, W.; Mitchell, B. Evaluation of water quality and management of Hongze Lake and Gaoyou Lake along the Grand Canal in Eastern China. Environ. Monit. Assess. 2011, 176, 373-384. [CrossRef] [PubMed]

19. Jin, X.; Xu, Q.; Huang, C. Current status and future tendency of Lake Eutrophication in China. Sci. China Ser. C Life Sci. 2005, 48, 948-954.

20. Huang, L.; Sun, K.; Ban, J.; Bi, J. Public perception of blue-algae bloom risk in Hongze Lake of China. Environ. Manag. 2010, 45, 1065-1075. [CrossRef] [PubMed]

21. Cui, C.; Hua, W.; Yuan, G.; Jiao, X.; Lv, Y. Assessment and Trend Analysis on Water Quality in Hongze Lake. China Resour. Compr. Util. 2013, 31, 44-47.

22. Ren, Y.; Pei, H.; Hu, W.; Tian, C.; Hao, D.; Wei, J.; Feng, Y. Spatiotemporal distribution pattern of cyanobacteria community and its relationship with the environmental factors in Hongze Lake, China. Environ. Monit. Assess. 2014, 186, 6919-6933. [CrossRef] [PubMed]

23. Han, S.; Huang, J.; Zhang, L. Influence analysis of water level variation on water quality in Hongze Lake. Water Resour. Power. 2015, 33, 30-33.

24. Ye, C.; Li, C.; Wang, B.; Zhang, J.; Zhang, L. Study on building scheme for a healthy aquatic ecosystem of Lake Hongze. J. Lake Sci. 2011, 23, 725-730.

25. Sharma, M.; Kansal, A.; Jain, S.; Sharma, P. Application of multivariate statistical techniques in determining the spatial temporal water quality variation of Ganga and Yamuna rivers present in Uttarakhand state, India. Water Qual. Expo. Health 2015, 7, 567-581. [CrossRef]

26. Li, D.; Huang, D.; Guo, C.; Guo, X. Multivariate statistical analysis of temporal-spatial variations in water quality of a constructed wetland purification system in a typical park in Beijing, China. Environ. Monit. Assess. 2015, 187, 4219. [CrossRef] [PubMed]

27. Monica, N.; Choi, K. Temporal and spatial analysis of water quality in Saemangeum watershed using multivariate statistical techniques. Paddy Water Environ. 2016, 14, 3-17. [CrossRef]

28. Kim, J.Y.; Bhatta, K.; Rastogi, G.; Muduli, P.R.; Do, Y.; Kim, D.K.; Pattnaik, A.K.; Joo, G.J. Application of multivariate analysis to determine spatial and temporal changes in water quality after new channel construction in the Chilika Lagoon. Ecol. Eng. 2016, 90, 314-319. [CrossRef]

29. Pratt, B.; Chang, H. Effects of land cover, topography, and built structure on seasonal water quality at multiple spatial scales. J. Hazard. Mater. 2012, 209, 48-58. [CrossRef] [PubMed]

30. Shrestha, S.; Kazama, F. Assessment of surface water quality using multivariate statistical techniques: A case study of the Fuji River Basin, Japan. Environ. Model. Softw. 2007, 22, 464-475. [CrossRef]

31. Garnier, J.; Leporcq, B.; Sanchez, N.; Philippon, X. Biogeochemical mass-balance (C, N, P, Si) in three large reservoirs of the Seine Basin (France). Biogeochemistry 1999, 47, 119-146.

32. El-Zeiny, A.; El-Kafrawy, S. Assessment of water pollution induced by human activities in Burullus Lake using Landsat 8 operational land imager and GIS. Egypt. J. Remote Sens. Space Sci. 2017, 20, S49-S56. [CrossRef] 
33. Liu, W.; Zhang, Q.; Liu, G. Lake eutrophication associated with geographic location, lake morphology and climate in china. Hydrobiologia 2010, 644, 289-299. [CrossRef]

34. Şener, S..; Şener, E.; Davraz, A. Evaluation of water quality using water quality index (WQI) method and GIS in Aksu River (SW-Turkey). Sci. Total Environ. 2017, 584, 131-144. [CrossRef] [PubMed]

35. Wang, Q.; Li, Z.; Lian, Y.; Du, X.; Zhang, S.; Yuan, J.; Liu, J.; De Silva, S.S. Farming system transformation yields significant reduction in nutrient loading: Case study of Hongze Lake, Yangtze River Basin, China. Aquaculture 2016, 457, 109-117. [CrossRef]

36. Liyanage, C.P.; Yamada, K. Impact of Population Growth on the Water Quality of Natural Water Bodies. Sustainability 2017, 9, 1405. [CrossRef]

37. Kragh, T.; Sand-Jensen, K.; Petersen, K.; Kristensen, E. Fast phosphorus loss by sediment resuspension in a re-established shallow lake on former agricultural fields. Ecol. Eng. 2017, 108, 2-9. [CrossRef]

38. Ball, E.E.; Smith, D.E.; Anderson, E.J.; Skufca, J.D.; Twiss, M.R. Water velocity modeling can delineate nearshore and main channel plankton environments in a large river. Hydrobiologia 2018, 815, 125-140. [CrossRef]

39. Estigoni, M.V.; Miranda, R.B.; Mauad, F.F. Hydropower reservoir sediment and water quality assessment. Manag. Environ. Qual. Int. J. 2017, 28, 43-56. [CrossRef]

40. Dodds, W.K. The role of periphyton in phosphorus retention in shallow freshwater aquatic systems. J. Phycol. 2010, 39, 840-849. [CrossRef]

41. Sánchez, M.L.; Pizarro, H.; Tell, G.; Izaguirre, I. Relative importance of periphyton and phytoplankton in turbid and clear vegetated shallow lakes from the Pampa Plain (Argentina): A comparative experimental study. Hydrobiologia 2010, 646, 271-280. [CrossRef]

42. Kanyiginya, V.; Kansiime, F.; Kimwaga, R.; Mashauri, D.A. Assessment of nutrient retention by Natete wetland Kampala, Uganda. Phys. Chem. Earth Parts A/B/C 2010, 35, 657-664. [CrossRef]

43. Calheiros, C.S.; Rangel, A.O.; Castro, P.M. Constructed wetland systems vegetated with different plants applied to the treatment of tannery wastewater. Water Res. 2007, 41, 1790-1798. [CrossRef] [PubMed]

44. Srivastava, J.; Gupta, A.; Chandra, H. Managing water quality with aquatic macrophytes. Rev. Environ. Sci. Bio/Technol. 2008, 7, 255-266. [CrossRef]

45. Vagnetti, R.; Miana, P.; Fabris, M.; Pavoni, B. Self-purification ability of a resurgence stream. Chemosphere 2003, 52, 1781-1795. [CrossRef]

46. Zhou, W.; Guo, X.; Chen, W.; Hu, W.; Chen, K.; Zhang, S.; Sui, G.; Ren, B.; Wu, M. Prediction of effects of first stage project of eastern route south-to-north water transfer from the changiang river on aquatic organism and ecological environment in hongze lake. J. Lake Sci. 1994, 6, 131-135.

47. Gove, N.E.; Edwards, R.T.; Conquest, L.L. Effects of scale on land use and water quality relationships: A longitudinal basin-wide perspective. JAWRA J. Am. Water Resour. Assoc. 2010, 37, 1721-1734. [CrossRef]

48. Bellinger, B.J.; Hoffman, J.C.; Angradi, T.R.; Bolgrien, D.W.; Starry, M.; Elonen, C.; Jicha, T.M.; Lehto, L.P.; Seifert-Monson, L.R.; Pearson, M.S.; et al. Water quality in the St. Louis River Area of Concern, Lake Superior: Historical and current conditions and delisting implications. J. Gt. Lakes Res. 2016, 42, 28-38. [CrossRef]

49. Vuorenmaa, J.; Rekolainen, S.; Lepistö, A.; Kenttämies, K.; Kauppila, P. Losses of nitrogen and phosphorus from agricultural and forest areas in Finland during the 1980s and 1990s. Environ. Monit. Assess. 2002, 76, 213-248. [CrossRef] [PubMed]

50. Xu, H.; Paerl, H.W.; Qin, B.; Zhu, G.; Gaoa, G. Nitrogen and phosphorus inputs control phytoplankton growth in eutrophic lake Taihu, China. Limnol. Oceanogr. 2010, 55, 420-432. [CrossRef]

51. Yazdi, J.; Moridi, A. Interactive reservoir-watershed modeling framework for integrated water quality management. Water Resour. Manag. 2017, 31, 2105-2125. [CrossRef]

(C) 2018 by the authors. Licensee MDPI, Basel, Switzerland. This article is an open access article distributed under the terms and conditions of the Creative Commons Attribution (CC BY) license (http:/ / creativecommons.org/licenses/by/4.0/). 